\title{
Kent Dışı Otoyollardaki Hatalı Dever Tespitine Yönelik Gömülü Sistem Uygulaması
}

\author{
Ahseni Bilgin Firikçi1 ${ }^{1}$, Kutan Koruyan²* \\ ${ }^{1}$ MKS DevO Kimya, Balıkesir, Türkiye \\ ${ }^{2}$ Yönetim Bilişim Sistemleri Bölümü, Dokuz Eylül Üniversitesi, İzmir, Türkiye
}

\section{$\ddot{O} z$}

Bu çalışma Karayolları Genel Müdürlüğü’ndeki yol bakım onarım çalışmalarında karar verici kişilere bir karar destek sistemi uygulaması geliştirmeyi amaçlamıştır. Çalışmada araç üzerinde veri toplayan gömülü sistem uygulaması ile karayolu üzerinde uygulanan enine eğim yani dever değerinin ölçümü yapılarak hatalı veya kaza potansiyeli bulunan yol noktaları belirlenmeye çalışılmıştır. Çalışma kapsamında maliyeti düşük performansı yüksek en iyi ivmeölçer ve jiroskop sensörleri kullanılmıştır. Belirlenen donanım araçlarının kalibrasyonları yapılarak sayısal veri alımlarında en düşük hata payına sahip olması ve yapılan ölçümlerin evrensel ölçüde doğruluk sağlaması amaçlanmıştır. Uygulama çalışması İzmir çevre yollarından E-881, E-87 ve D300 otoyollarında yapılmıştır. Çalışma kapsamında elde edilen veriler coğrafi bilgi sistemleri kullanılarak görselleştirilmiş ve analiz edilmiştir.

Anahtar Kelimeler: dever, yalpa açısı, ivmeölçer, jiroskop, gömülü sistem

\section{Embedded System Application Intended for Detecting Faulty Superelevation on out of City Highways}

\begin{abstract}
This study aims at developing a decision support systems application for people in General Directorate of Highways' decision makers in road maintenance and repair work. In the study, with the application of embedded system that collects data on the vehicle, the transverse slope applied on the highway, that is, the superelevation was measured, and it was tried to determine the road points with faulty or accident potential. The best accelerometer and gyroscope sensors with low cost and high performance were used within the scope of the study. By performing calibration of the determined hardware tools, it is aimed to have the lowest error margin in digital data acquisition and to ensure universal accuracy of the measurements made. The application study was carried out on the E-881, E-87 and D-300 highways from İzmir ring roads. The data obtained in this study were analysed and visualized by using geographic information systems.
\end{abstract}

Keywords: superelevation, roll angle, accelerometer, gyroscope, embedded system

\footnotetext{
* İletişim / Contact: Kutan Koruyan, Yönetim Bilişim Sistemleri Bölümü, Dokuz Eylül Üniversitesi, İzmir Türkiye. E-Posta / Email: kutan.koruyan@deu.edu.tr.

Gönderildiği tarihi / Date submitted: 17.08.2021, Kabul edildiği tarih / Date accepted: 4.10.2021

Alıntı / Citation: Firikçi, A. B. ve Koruyan, K. (2021). Kent Dışı Otoyollardaki Hatalı Dever Tespitine Yönelik Gömülü Sistem Uygulamas1. Trafik ve Ulaşım Araştırmaları Dergisi, 4(2), 65-83. doi:10.38002/tuad.983482
} 


\section{Kent Dışı Otoyollardaki Hatalı Dever Tespitine Yönelik Gömülü Sistem Uygulaması}

Otoyollardaki virajlarda hareket halindeki karayolu taşıtlarına birtakım kuvvetler etkir. $\mathrm{Bu}$ kuvvetler virajı dönmekte olan araca, viraj yönünün tersi yönde bir etki uygular (Charbeneau, Jeong ve Barrett, 2008). Bu etkinin ortadan kaldırılarak aracın güvenle virajı dönmesi için yol üzerinde, viraj yönüne doğru enine bir eğim verilir (Yayla, 2004). Bu enine verilen eğime dever denilmektedir (Şekil 1). Yola uygulanan dever açısının $(\alpha)$ belirlenmesinde birçok kriter bulunmaktadır. Bu kriterlerin başında dever uygulanacak yolun yol geometrisinin el verdiği en yüksek hız olan proje hızı gelmektedir. Çünkü yol üzerinde uygulanacak dever, aracın belirli bir süratle güvenli dönüş yapmasını sağlamaya yöneliktir. Belirlenen hız faktörüne göre yol üzerinde seyreden araçların \%85'i proje hızını aşmamalıdır (Akpınar, 2017).

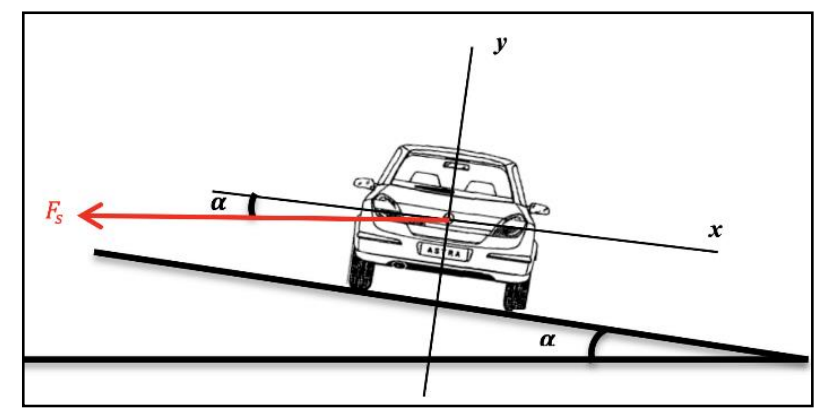

Şekil 1. Kurba (Viraj) Üzerindeki Taşıtı Dışa Doğru İten Kuvvet $\left(F_{s}\right)$ ve Dever Açısı (a)

2000 ile 2011 yılları arasında gerçekleştirilen ve 112 adet kaza alanında yapılan bir araştırma, kazaların meydana gelmesindeki en etkili faktörün yola uygulanması gereken deverin ölçü standartlarından daha yüksek uygulanmış olduğunu göstermektedir (Lim ve Choi, 2011). 2018 yılında Ankara il sınırları içerisinde yapılan bir araştırmaya göre trafik kazalarının \%31'i dever uygulanan yol üzerinde olmuştur (Uyurca ve Atılgan, 2018). Emniyet Genel Müdürlüğü ve Jandarma Genel Komutanlığı trafik kaza verilerine göre düzenlenen Karayolları Genel Müdürlüğü'nün ([KGM], 2021) 2020 yılına ait trafik kazaları özetine göre en fazla kaza olan yerlerin yatay güzergahlar olduğu anlaşılmıştır. Aynı yayında deverin araca uyguladığı etkiyle kaza durumları ilişsilendirilip, 2020 yılında yoldan çıkma, devrilme, savrulma ve takla neticesinde meydana gelen trafik kazalarının oranları toplandığında, tüm kazalar içindeki oran yerleşim yerlerinde $\% 17,54$, yerleşim yeri dışında ise $\% 53,23$ olduğu belirlenmiştir. Trafik kazalarının en çok yaşandığı yatay güzergahlardaki dever üzerinde mühendislik hatalarının olabileceğine ilişsin çalışmalar bulunmaktadır (Ünal ve Çodur, 2017). Kamyon ve bir otobüsün yatay güzergâh üzerinde karıştığı kaza noktasında yapılan bir çalışmaya göre deverin kazanın olduğu yol üzerinde sadece $\% 3$ olarak uygulandığı ve bunun da kaza potansiyelini arttıran bir etmen olduğu belirtilmiştir (Sulistyono, Kriswardhana ve Hayati, 2020). Bu kazalar; dever, yatay yarıçap, yatay hizalama, görünürlük faktörlerine bağlı olarak hatalı mühendislik hesaplamaları yüzünden olmaktadır (Patil, Attar, Dugani, Desai ve Mahabri, 2019).

Karayolları ve demiryolları yapımında uygulanan dever değerini ölçmek için birçok ölçüm tekniği kullanılmaktadır. Günümüzde bu tekniklerden bazıları yüksek ölçüm hassasiyetine sahip lazerli elektronik takeometre, GNSS, LIDAR gibi ölçüm teknikleridir. Yol üzerine uygulanan dever değerleri ülkelere göre değişiklik gösterebilmektedir. Örneğin, Amerika Birleşik Devletleri'nde kent dişı otoyollarda bu değer maksimum \%12, Almanya'da ise maksimum \%7'dir (Design Quality Assurance Bureau, 2003; Lamm, 1984). Türkiye'de ise dever $\% 8$, don ve buzlanma görülen yerlerde $\% 6$, minimum dever ölçüsü çok şeritli yollarda $\% 2,5$, çift şeritli yollarda ise \%2 olarak belirlenmiştir (KGM, 2016). Dever karayolu standartlarına göre doğru verilmiş olsa dahi birçok faktör (zamanla aşınan yol yüzeyleri ve 
standart altı inşaatlar, vb.) potansiyel olarak yetersiz dever değerlerini üretebilir. $\mathrm{Bu}$ da ciddi karayolu kazalarına sebebiyet verebilmektedir (Tsai ve Ai, 2017).

Türkiye'de yol üzerindeki \%8'lik dever sınırı yaklaşık 4,57 dereceye karşılık gelmektedir. Bu durumu eğimin her iki yönü içinde düşünüldüğünde yola uygulanacak deverin karşıllı̆ı; sağa virajda, eğim sola yatık olacağı için dever açısı $-4,57^{\circ}<a<0^{\circ}$, sola virajda, eğim sağ yatık olacağı için dever açısı $0^{\circ}<a<4,57^{\circ}$ aralığında olacaktır. Bu ölçüm kriterlerinin doğru bir biçimde yapılıp yapılmadığı, zamanla değişen yol noktalarının tespiti ve bakım onarım çalışmalarına ön rapor düzeyinde bilgi sunulması, otoyol üzerindeki kusurların tespit edilerek taşıt seyrinin güvenli kılınması ve kurumlarda zaman, maliyet ve işgücü faktörlerinde fayda sağlanması kritik önem taşımaktadır. Bu yüzden, karayollarındaki dever açısı hataların az bir maliyetle ve gömülü sistemler gibi teknolojinin getirdiği pratik ve geliştirilebilir yöntemlerle belirlenebilmesi bu çalışmanın çıkış noktasını oluşturmuştur.

Karayolu tasarımında yatay güzergahlarda bulunan dever ölçüsünün önemine rağmen araç güvenliği ile ilgili çok fazla araştırma bulunmamaktadır (Pasias, Apostoleris, Matragos, Mertzanis ve Mavromatis, 2020). Çalışma konusuna örnek olacak çalışmalar sınırlı olup, gömülü bilgisayarlarla birlikte entegre olarak çalışan jiroskop ve eğimölçer cihazlarıyla yapılan uygulamalar bulunmaktadır. Buna ek olarak, mobil uygulama veya kaza noktalarında yapilan eğim ölçümleri sonucunda simülasyon çalışmaları örnek olarak gösterilebilir. Yapılan bir çalışmada araç üzerinde yol geometrisinde meydana gelen bozuklukların trafik kazalarına etkisi ivme ve Küresel Konumlandırma Sistemi (GPS) sensörleri kullanarak araştırılmıştır (Tuncel ve Baybura, 2011). Başka bir çalışmada ise ivmeölçer ve jiroskop sensörlerini akıllı telefon GPS'i ile koordinasyonu sağlanarak yolun eğimi ölçülmeye çalışılmış ve kullanılan bu yöntemle akıllı telefonla birlikte koordine sağlayan harici ivmeölçer ve jiroskop sensörlerinin ölçüm kalitesinin yüksek olduğu belirtilmiştir (Gupta ve ark., 2020). Başka bir çalışmada yine ivme ve GPS sensörleri kullanarak yol üzerinde bulunan yüzey bozuklukları çukur veya tümsekler tespit edilmeye çalış1lmıştır (Soytürk, Doğan, Şaşmaz ve Böyük, 2014). Diğer bir çalışmada ise lazerli eğim ölçümünün yanında düşük maliyetli ivme ve jiroskop sensörlerlerinin mobil uygulama ile entegrasyonu sağlanarak araç üzerinde yolun dever değeri ölçülmüştür (Tsai ve Ai, 2017).

$\mathrm{Bu}$ çalışmanın önceden yapılan araştırma ve çalışmalardan farklı yanı, otoyol üzerine uygulanan deverin hareket halindeki taşıt üzerinde hiçbir uygulamadan yardım almadan tamamen gömülü sistem donanım araçları ve yazılımıyla ölçülmesidir. Önceki çalışmalara ek olarak sadece donanım ve yazılım tarafı değil verilerin elde edilmesinde büyük öneme sahip çalışma aracının üzerinde de incelemeler yapılmıştır. $\mathrm{Bu}$ incelemeler genellikle çalışma aracının süspansiyon sistemi, lastik hava basıncı, lastik hamur tipi, çevresel faktörler, yol eğiminin araç stabilitesi üzerindeki etkileri ve bu etkilerin ölçümleri hangi oranda değiştireceği gibi incelemelerdir. Bu yönüyle bu çalışma önceden yapılan araştırmalardan farklı olarak otoyollara uygulanan dever ölçülerini gömülü sistem uygulaması ile birlikte çalışma aracının hareket stabilitesine göre analiz ederek farklı bir bakış açısı ve yenilik sunmaktadır.

\section{Yöntem}

Bilişim teknolojilerinin ilerlemesiyle birlikte mobil cihazlar entegre edilebilir, hesaplama açısından verimli ve son derece düşük maliyetli hale gelmiştir. Bu cihazlardaki GPS ve video kameralar gibi entegre sensörlerden yararlanarak, birçok ulaşım uygulaması başarıyla geliştirilmiştir. İvmeölçer ve jiroskop gibi entegre sensörler ile de mobil cihazlar yatay eğim değerlerinin ölçülmesinde uygun maliyetli, güvenilir veri toplanmasını desteklemek için mükemmel adaylar haline gelmişlerdir (Tsai ve Ai, 2017).

Bu çalışmada, kent dışı otoyollarda dever değerinin standartlar dahilinde yol üzerine uygulanıp uygulanmadığı veya doğal faktörlere bağlı olarak yol geometrisinin değişmesi sebebiyle 
deverin de olumsuz etkilendiği yol noktalarının tespit edilmesi amaçlanmıştır. Bunun için araç üzerinde yol eğimini ve yol eğiminin araç üzerine etkisini ölçen eğim sensörü, aracın yanal enlemde hareket halini bilmek için jiroskop sensörü ve alınan verilerin hangi yol noktaları üzerinde yer aldığını bilmek için ise GPS sensörü kullanılmıştır. Farklı sensörlerin koordineli olarak araç üzerinde çalışması ve sensörlerden verilerin elde edilerek kayıt altına alınmasını sağlamak için Python programlama dilinden yararlanılmıştır. Kullanılan bütün sistem parçaları tek kart bilgisayar (single-board computer) olan Raspberry Pi üzerinde çalıştırılmıştır. Belirlenen güzergâh noktalarından elde edilip kayıt altına alınan verilerin incelenmesi ve çeşitli sorgular, konuma bağlı olarak Coğrafi Bilgi Sistemleri (CBS) yardımıyla yapılmıştır. Yapılan incelemeler sonucunda dever açısının karayollarında belirlenen standart değerlerden az veya fazla olduğu tespit edilmeye çalışılmıştır. Çalışma kapsamında veri eldesinin geçtiği aşamalar Şekil 2'de gösterilmiştir.

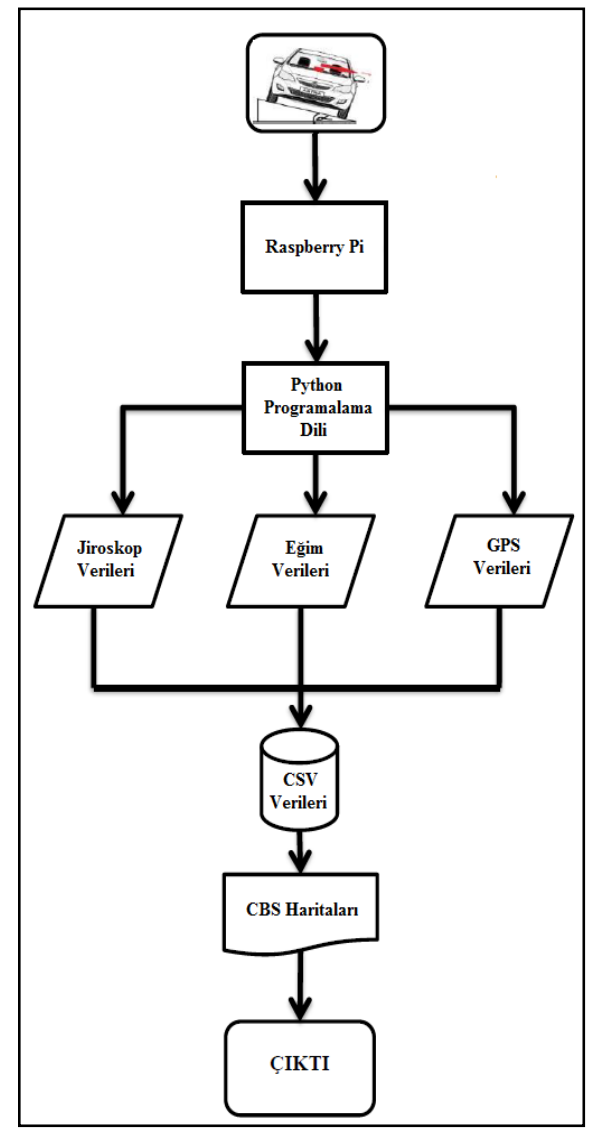

Şekil 2. Çalışma Akış Şeması

\section{1. Çalışmada Kullanılan Donanım Araçları}

Çalışma kapsamında yol verilerinin alımında ana koşulları oluşturan ve bir binek araca monte edilen bazı donanım araçları kullanılmıştır. Bu donanım bileşenleri sırasıyla şu şekildedir:

- Raspberry Pi 3B+: Veri alım sürecinde önemli bir rol oynayan bu kartın üzerinde giriş veya çıkış olarak kullanıcı tarafından belirlenen dijital sinyal pinleri bulunmaktadır.

- LG Monitör: Çalışan devre kartından gelen görüntüyü aktarması için kullanılmıştır.

- NXP (fxos8700 + fxas21002) İvme + Jiroskop Sensörü: Çalışma kapsamında devre kartıyla birlikte çalışan donanım araçlarıdır.

- Neo6mv2 GPS Modülü: Konum belirleme ve araç hızının ölçümünü yapmaktadır.

- Yapışkan Mini Breadboard: Sensörün düz bir yüzey üzerinde sabitlenmesi için kullanılmıştır. 


\subsubsection{Jiroskop Sensörünün Dever Ölçümündeki Yeri.}

Jiroskop sensörü sabit bir nesnenin üç dikey eksende açısal oranlar karşılaştırılarak dönüş yönü ve hızını belirleyen sensördür. Açısal dengenin korunması ilkesiyle çalışır. Çalışma prensibi olarak jiroskop sensörü açısal hızı algılayabilir. Yani sabit duran bir cismin, üç dikey eksende açısal oranlar karşılaştırılarak dönüş yönü ve dönüş hızı belirlenir (Süzen, Deniz ve Çetin, 2017). Bu sayede çalışma kapsamında hareket eden aracın yönü ve dönüş halindeki eksen değeri net olarak bilinebilmektedir. Seyir halindeki aracın direksiyon hareketlerine göre değişen bu değer jiroskop verileri içerisinde $Z$ ekseninde gösterilmektedir. Jiroskop ölçümü sonucunda eğer $0>Z \geq 2,999999$ ise araç düz gitmekte, eğer $Z \geq 3$ ise araç sola dönmekte ve eğer $Z<0$ ise araç sağ dönmektedir.

\subsection{2. İvme Sensörünün Dever Ölçümündeki Yeri.}

İvme sensörü yol üzerindeki dever değerinin kontrol edilmesinde ana faktör olan enine eğim açısının değerini $(x)$ araç üzerinde vermektedir. Yani dönüş yön bilgisine göre virajlarda araç gövdesine uygulanan eğimin veya yol üzerindeki deverin eğim değerini ölçülebilmektedir. İvme sensörü araç düz konumda iken aldığı veriler dever ile örtüşme sağlasa da sağ veya sol virajda eğim sensörleri ağırlık merkezinin değişmesiyle yalpa açısının yani araç gövdesinin salınım açısının değerini ölçecektir. O halde yol verisi alımında dikkat edilmesi gereken nokta yaylanmış kütle kavramıdır. Çünkü bu kavramın çalışmaya etkisi özellikle virajlarda meydana gelen dönüş esnasında süspansiyon yaylarının araç gövdesine yaptığı etkidir. Bu etki taşıtın yaylanmış kütlesinin, taşıtın rulo merkezinin etrafında dönmesi anlamına gelmektedir (VargasMeléndez, Beatriz, Baoda, Gauchía ve Díaz, 2016). Benzer bir çalışmada bu durum, aracın ani dönüş yapmadığ 1 ve düz konumda olduğu anda ivme sensörünün çok iyi çalıştığ belirtilmiştir (Nilsson ve Lingefelt, 2011). Sensörden alınan eğim değerinin, değişen araç seyrine göre açıklaması Tablo 1, Tablo 2 ve Tablo 3'deki gibidir.

Tablo 1. Sensör ĕğim değerinin düz araç seyrine göre açıklaması

\begin{tabular}{ll}
\hline Durum & Araç seyir hali düz iken \\
\hline$x>0$ & Dever yönü pozitiftir (Sensör sağa yatık bir düzlemin üzerinde bulunmaktadır). \\
$x<0$ & Dever yönü negatiftir (Sensör sola yatık bir düzlemin üzerinde bulunmaktadır).
\end{tabular}

Tablo 2. Sensör eğim değerinin düz araç seyrine göre açıklaması

\begin{tabular}{ll}
\hline Durum & Araç seyir hali düz iken (Dever yönü negatif olmalıdır). \\
\hline \multirow{3}{*}{$x>0$} & $\begin{array}{l}\text { Araç virajda değişen ağırlık merkezi sebebiyle, dever yönüne ters bir şekilde } \\
\text { yalpa açısı vererek, pozitif yönde değer vermiştir. Bu değerin en fazla }+7^{\circ} \text { olması } \\
\text { beklenir. }\end{array}$ \\
& $\begin{array}{l}\text { Araç virajda değişen ağırlık merkezi sebebiyle sensörde negatif yönde değer } \\
\text { vermiştir. Bu durum aracın viraj içine doğru hareket ettiği anlamına gelmektedir. }\end{array}$ \\
\hline
\end{tabular}

Tablo 3. Sensör ĕ̆im değerinin düz araç seyrine göre açıklaması

\begin{tabular}{ll}
\hline Durum & Araç seyir hali düz iken (Dever yönü pozitif olmalıdır). \\
\hline$x>0$ & Araç virajda değişen ağırlık merkezi sebebiyle dever yönüne ters bir şekilde \\
& yalpa açısı vererek negatif yönde değer vermiştir. Bu değerin en fazla $-7^{\circ}$ olması \\
& beklenir.
\end{tabular}

2.1.3. İvme Verilerinin Ĕ̆im Açılarına Dönüştürü̈lmesi.

İvme verileri FXOS8700 entegre sensöründen üç eksende yani Tablo 4'de gösterildiği üzere $x$, $y, z$ eksenleri halinde gelmektedir. Bu eksenler şu şekildedir; 
- $\quad x$ eksen ivmesi: Sensörün yanal eksendeki dönme ivmesini göstermektedir.

- $y$ eksen ivmesi: Sensörün dikey eksendeki dönme ivmesini göstermektedir.

- $\quad z$ eksen ivmesi: Sensörün sapma eksenindeki dönme ivmesini göstermektedir.

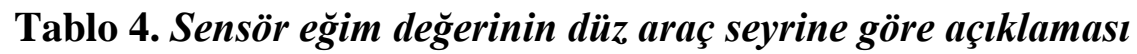

\begin{tabular}{ll}
\hline Açıklama & Örnek Bir Konumun İvme Değerleri (m/sn) \\
\hline İvmeölçer $X$ & $0,48=$ Ölçekli $\left(2,91.10^{-5}\right)$ \\
İvmeölçer $Y$ & $-1,33=$ Ölçekli $\left(-8,13 \cdot 10^{-5}\right)$ \\
İvmeölçer $Z$ & $9,86=$ Ölçekli $\left(6,02.10^{-4}\right)$ \\
\hline
\end{tabular}

Eğim açısını elde edebilmesini sağlayan ivme değerleridir. İvme değerleri bilindiği üzere kartezyen koordinat sisteminin bir parçasıdır. Eğim ise trigonometrik koordinat düzleminde yer almaktadır. Elde edilen ivme değerlerinden eğim verileri bulunabilmektedir. Bu işlem Python programlama dilinde kullanılan ve trigonometrik değerlerin yorumlanmasını sağlayan Atan2 fonksiyon metodu kullanılarak yapılmaktadır. Atan2 fonksiyonu başlangıç noktası ile bilinen $x, y$ koordinatları arasındaki doğrunun $X$ ekseniyle açısını radyan cinsinden döndürmektedir. Şekil 3'te Atan2 fonksiyonun çalışma metodu gösterilmektedir. Özetle elde edilen ivme değerleri üzerinde Atan2 metodu kartezyen koordinatlar ile trigonometrik koordinatlar arasında bir bağ kurmaktadır.

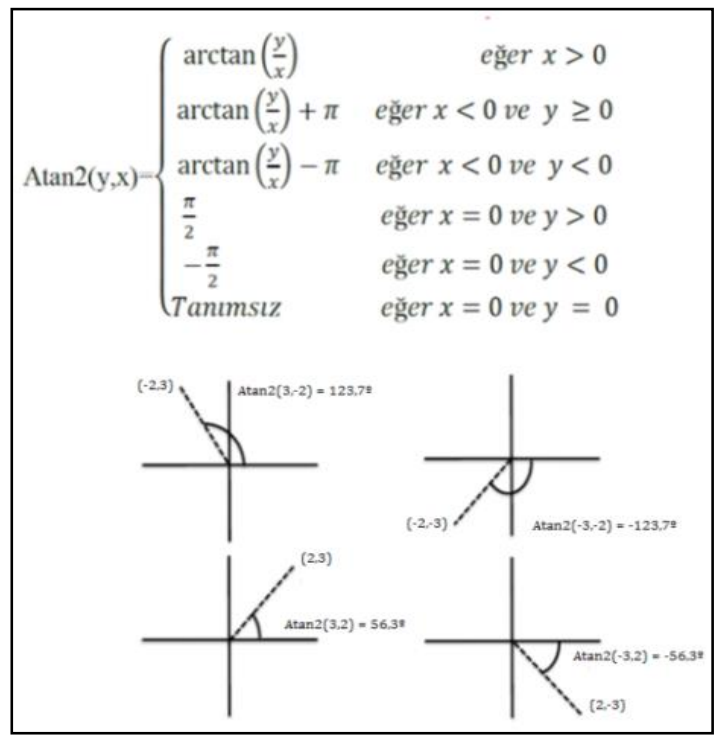

Şekil 3. Atan2 Fonksiyon Metodu

\subsection{Sensör Hataları}

Fabrika çıkışlı sensörlerin kendilerine özgü hata payları da bulunmaktadır. Bu hata payları kimi zaman sensör veri sayfalarında (Datasheet) yer alırken, kimileri ise test, gözlem, kontrol ve karşılaştırma sonucunda ortaya çıkmaktadır. Sensör hata payları fabrikasyon hatalar olarak gerçekleştikleri için kullanıcılar bu hataları büyük oranda giderememektedir. Bu sebeple hatalar göz önünde bulundurularak sonuca verdiği etkiye göre bir hesaplama yapmak daha doğru olacaktır. Çalışma kapsamında yer alan sensörlerden; eğim sensörü (ivme değerleri olan $x, y, z$ eksenindeki ölçüm hatası), jiroskop sensörü (yanal dönüş birimi olan $z$ eksenindeki ölçüm hatası) ve GPS sensörü hataları araştırılmıştır. 


\subsection{1. Ĕ̈im Sensörü Kalibrasyon Testi.}

Eğim sensörü ölçümlerinin gerçek değerden ne kadar saptığını bulmak için kalibrasyon testi gerekmektedir. Eğim sensörünün kalibrasyon testi için ST37 kaliteli sacdan lazer operasyonuyla kesilen metal yüzey kullanılmıştır. Bu metal yüzey daha sonra talaşı imalatla Şekil 4'te görüldügü gibi yüzeyi pürüzsüz hale getirilmiştir.

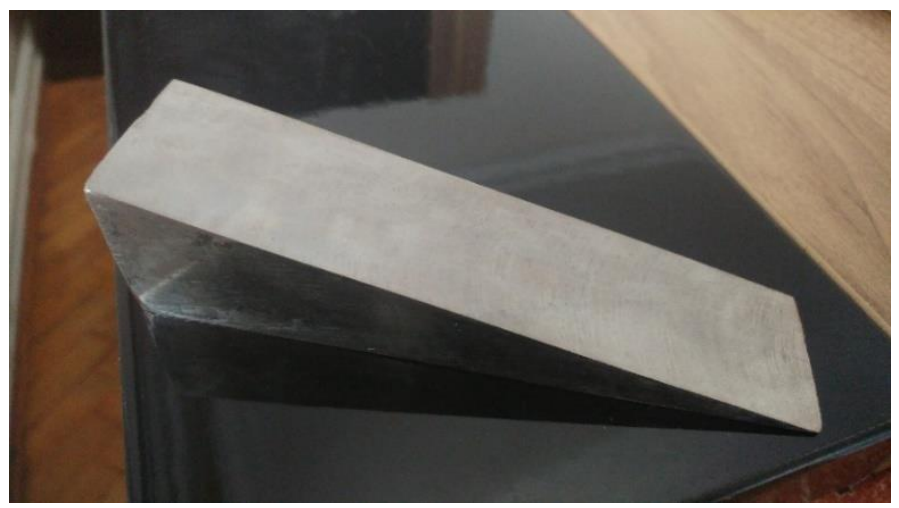

Şekil 4. Lazer operasyon ve talaşlı imalat sonrası kalibrasyon testi aksamı

Eğim açısının bulunması için aksamın yatay ve düşey kenarları hassasiyeti $\pm 0,02 \mathrm{~mm}$ olan kumpas ile 3 kere ölçülmüş ve aritmetik ortalamaları alınmıştır. Şekil 5 'te belirtilen A ve B kenar uzunluklarındaki ölçümler sonucunda açı, $a=\arctan (A / B)=13,69^{\circ}$ olarak hesaplanmıştır.

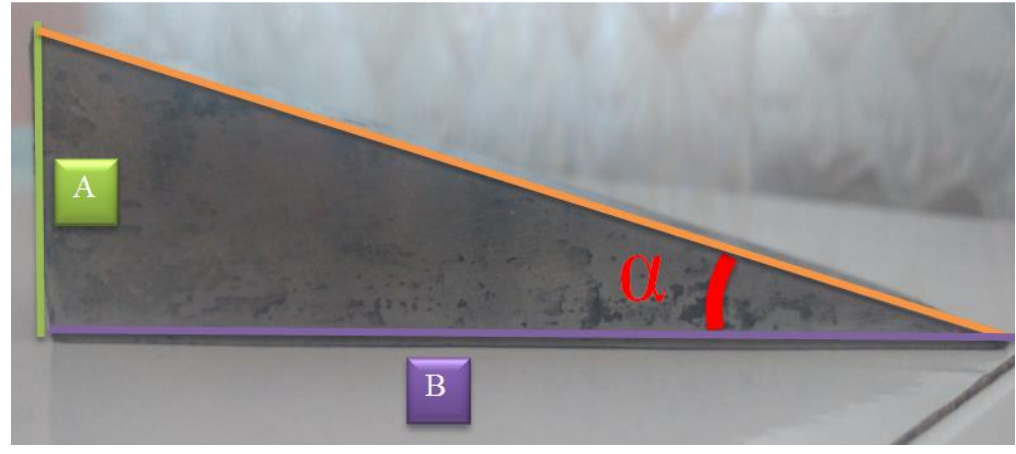

Şekil 5. Metal yüzey A ve B kenarlart

Yapılan kalibrasyon testinde uygulama sensörü olarak seçilen FXOS8700 sensörünün hesaplanan $13,69^{\circ}$ 'den ne kadar saptığı belirlenmektedir. Bu test için eğim sensörü metal yüzey ve zemin üzerinde iki farklı konumda Şekil 6'daki gibi test yapılmıştır. Sonuçlar Tablo 5'de verilmektedir.

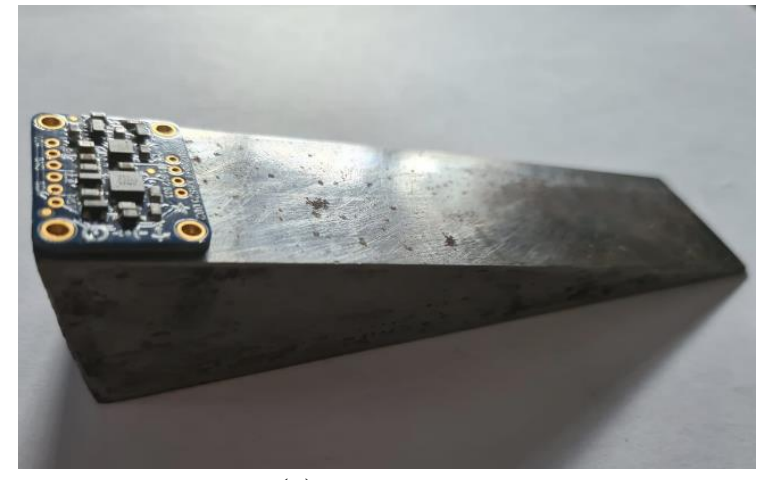

(a)

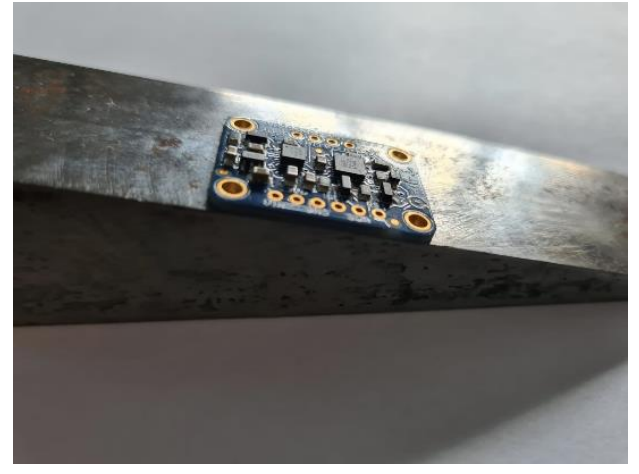

(b)

Şekil 6. Metal Yüzey Üzerindeki Sensör Testleri (a: Test 1, b: Test 2)

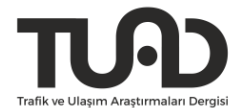


Tablo 5. Sensör ölçüm sonuçları

\begin{tabular}{lll}
\hline Durum & Test 1 & Test 2 \\
\hline Sapma Açıs & $1,57^{\circ}$ & $1,13^{\circ}$ \\
Zemin Üstündeki Metal Yüzeyin Yatayla Yaptığı Açı & $-11,44^{\circ}$ & $-11,92^{\circ}$ \\
Ölçüm Sonuç Değeri & $13,01^{\circ}$ & $13,05^{\circ}$ \\
\hline
\end{tabular}

Kalibrasyon testi, sonucu etkileyecek birtakım hususlar gözetilerek yapılmıştır. Bu hususlardan birisi ölçüm sonucunu etkileyecek olan kalibrasyon testinin gerçekleştiği zeminin eğim ölçüsüdür. Bu değer kalibrasyon testinden önce gelişmiş hassas ölçüm yapabilen iki adet eğim ölçer aygıtıyla ölçülerek Tablo 5'deki Test 1'de sapma açısı 1,57ºlarak gösterilmiştir. Sapma açısının üstüne yerleştirilen metal yüzeyin eğim değeri $13,69^{\circ}$ 'dir. Kalibrasyon testindeki sensörün metal yüzeyde ölçtüğü değer -11,44'dir. Sapma açısı pozitif yönde bir eğime sahiptir, bu sebeple sensörün negatif yönde -11,44 ölçüm yapmış olması sapma açısı ortadan kaldırıldığında sensörün $13,01^{\circ}$ 'lik ölçüm yaptığı sonucuna ulaşılmaktadır. Sonuç olarak sapma açısının ölçüm hesabına etkisi ortadan kaldırıldığında sensör metal yüzey üzerinde $13,01^{\circ}$ 'lik bir ölçüm gerçekleştirmiştir. Aynı kalibrasyon testi aynı koşullar altında zeminin farklı bir noktasında tekrar edilerek Tablo 5'de Test 2 olarak paylaşılmıştır.

Metal yüzey üzerine konan sensör gerekli hesaplamalar yapıldı̆̆ında eğim açısı değeri yaklaşık $13^{\circ}$ gösterdiğinden, kalibrasyon testiyle birlikte ortaya çıkan sonuca göre sensör $1^{\circ}$ de yaklaşık $0,05^{\circ}$ 'lik hata değerine, yani sensörün ölçüm yaptığı yüzey üzerinde $\% 5^{\prime}$ lik bir ölçüm hata payına sahip olmaktadır.

\subsubsection{Jiroskop Sensörü Z Ekseni Ölçüm Hatası.}

Jiroskop sensörü yapılan incelemeler sonucunda açısal dönüş yönlerinden sağ yönü negatif olarak belirtirken, açısal sola dönüş derecesini $2,99^{\circ}$ 'den sonra vermektedir. Bunun tespit edilmesi sensörün düz konumda $0^{\circ}$ ile $2,99^{\circ}$ arasında değer alması ile belirlenmiştir.

\subsubsection{GPS Ölçüm Hatası.}

GPS sensörünün üretici firma tarafindan paylaşılan veri sayfasında 2,5 m'lik bir konum sapması olduğu belirtilmiştir. Fakat bu değer kabul edilebilir olarak görülmüş ve çalışma kapsamında paylaşılan bu hata payı ihmal edilmiştir.

\subsection{Kullanılan Aracın Özellikleri}

Çalışma kapsamında kullanılan aracın özellikleri Tablo 6'da verilmektedir.

Tablo 6. Çalışmada kullanılan aracın özellikleri

\begin{tabular}{ll}
\hline Model Yılı & 2005 \\
Motor Hacmi & 1,6 \\
Kasa Tipi & Hatchback (binek) \\
Ön-Arka Aks Aralığı & $2614 \mathrm{~mm}$ \\
Aks Mesafesi & $1753 \mathrm{~mm}$ \\
Net Yatay Uzunluğu & $4249 \mathrm{~mm}$ \\
Net Dikey Uzunluğu & $1467 \mathrm{~mm}$ \\
Net Genişlik Uzunluğu & $2033 \mathrm{~mm}$ \\
Teker Boyut Ölçüleri & $205 / 55 / \mathrm{R} 16$ \\
Boş Ağırlık & $1265 \mathrm{~kg}$ \\
\hline
\end{tabular}




\subsection{Araç İçi Sensörün Konumlandırılması}

Yol eğim verilerinin ve yolun araca uyguladığı enine eğim verilerinin en sağlıklı alınacağı araç içi nokta, gövdenin altında bulunan akslara ve süspansiyona yakın kısımlardır. Fakat buraya konacak bir sensörün, araç içinde çalışmak zorunda olan bilgisayar sistemiyle bağlantısı araç dışı faktörler yüzünden (rüzgâr, sabitlemede yaşanan bir takımlar sorunlar veya bağlantı kablolarının iletim sağlayamaması gibi) oldukça zor olacaktır. Bu yüzden sensör araç içinde düz bir noktada sabitlenmiştir. Şekil 7'de uygulama aracının orta noktasındaki sensör alanı gösterilmiştir.
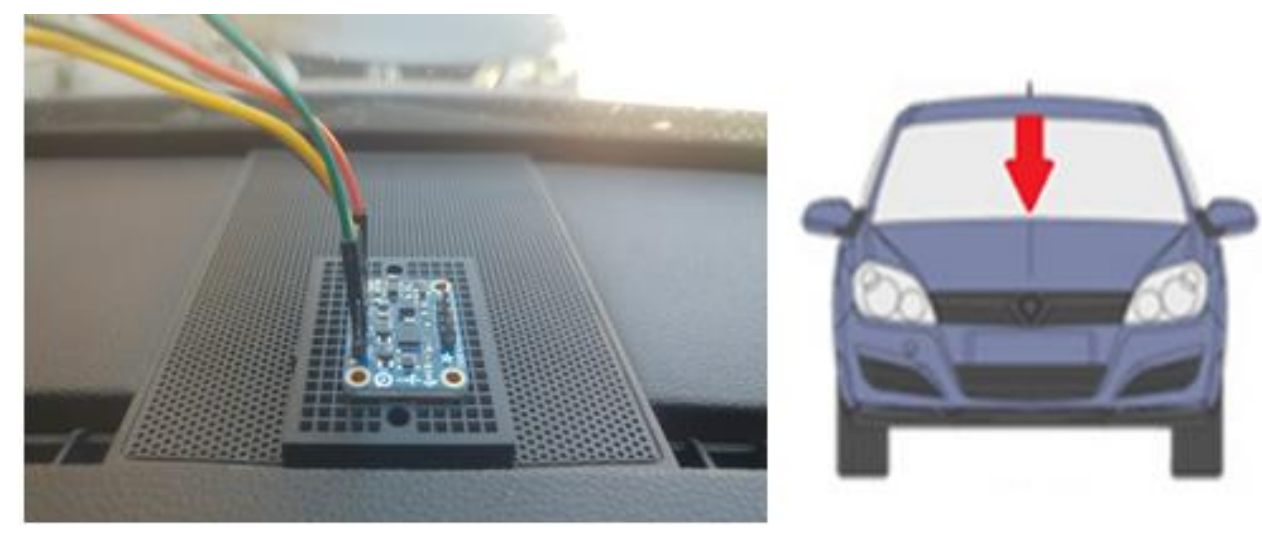

Şekil 7. Araç Iç̧i Sensör Noktası Taslakla Beraber İç Görünüm

\subsection{Yazılım Bileşenleri}

Çalışma kapsamında GPS ve entegre kart şeklinde olan jiroskop ve eğimölçer sensörü çalışmaktadır. Sensörlerin çalışması ve verilerin elde edilmesi için Python 2.7 programlama dilinden yararlanılmıştır. Elde edilen veriler konuma bağlı olarak QGIS CBS yazılımı yardımıyla haritalar üzerinde görselleştirilmiş ve belirlenen ölçüm kriterleri ile sorgulama sonucunda aynı konum üzerinde sıralı olarak hata veren yol noktaları gösterilmiştir.

\subsection{Uygulama}

İvme, jireskop ve GPS'den elde edilen veriler terminal ekranında (Şekil 8) enlem, boylam, araç hızı $(\mathrm{km} /$ saat), ivme ölçer verileri $(x, y, z)$, araç yön bilgisi, $x$ yönünde yatay eğim, $y$ yönünde dikey eğim olarak gösterilmektedir. Kriter önceliklerinin belirlenmesinin ilk aşamasında, yukarıda belirtilen kaynaklardan faydalanarak üç ana ve dokuz alt kriter olmak üzere toplamda 12 kriter oluşturulmuştur. Belirlenen kriterlere ait açıklamalar aşağıda detaylı paylaşılmıştır.

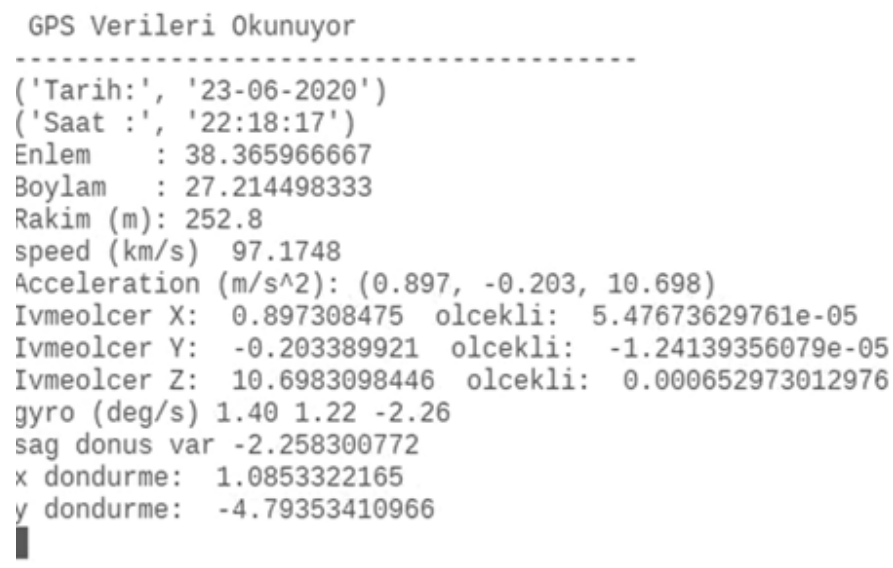

Şekil 8. Terminal Ekranında Sensör Verileri 


\subsection{1. Çalışma Sahası.}

Çalışma sahası olarak kent dişı otoyollardan İzmir çevresinde bulunan D300, E881, E87 otoyollarının belirli kısımları seçilmiştir. 1. grup Buca-Bornova hattı olup E881, E87 yollarının bir kısmını kapsamakta, 2. grup ise Buca-Üçkuyular hattı olup E881, D300 yollarının bir kısmını kapsamaktadır. Çalışma bölge sahası olarak seçilen bu noktalar Şekil 9'de harita üzerinde gösterilmiştir.

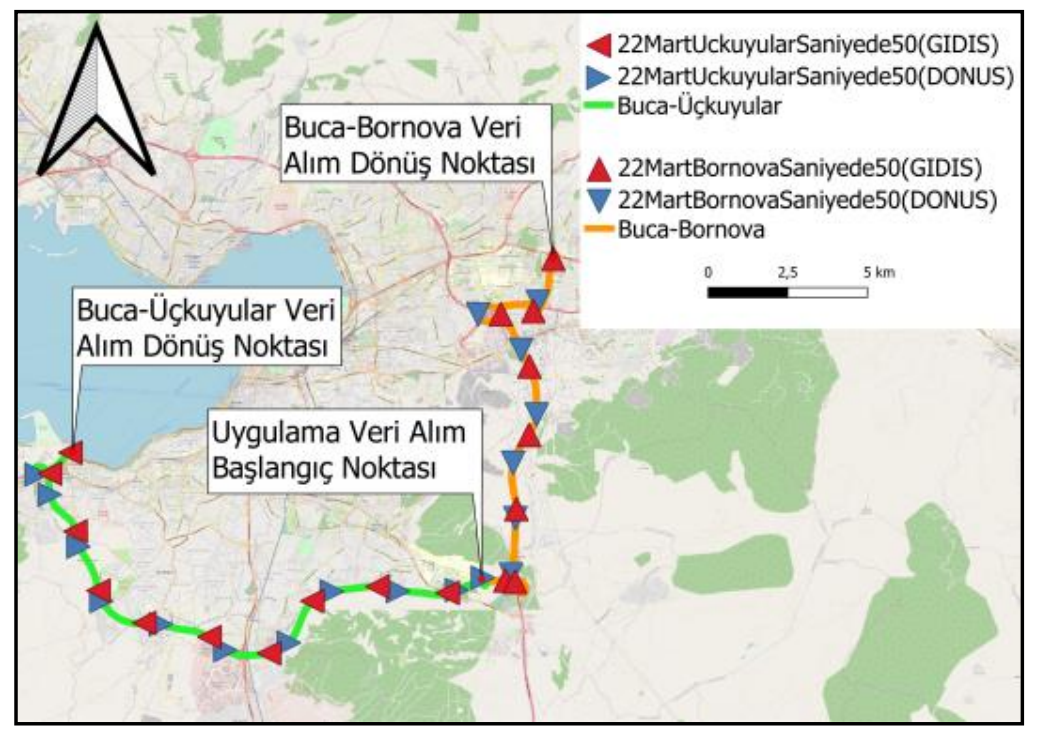

Şekil 9. Buca-Üçkuyular ve Buca-Bornova Yol Güzergahı

\subsection{2. Çalışma Veri Analiz Değerlerinin Belirlenmesi.}

Çalışma kapsamında çalışan sensörler eğimi yüzdesel olarak değil derece olarak vermektedir. Bu sebeple yüzdesel verilen deverin derece karşılığı hesaplanmıştır. Belirlenen ölçüm kriterleri aracın yol üzerinde seyir halinde karşılaştığı kuvvetlere göre belirlenmiştir. Çalışmanın ölçüme göre elde edilmesi amaçlanan değer dever değeridir. Fakat virajlarda çalışmada kullanılan araç dever değerini değil yalpa açısını ölçmektedir. Bu ölçümden dolaylı olarak deverin standartlara uygun olarak verilip verilmediği de incelenmiştir. O halde, araç üzerinde dever ölçümü için doğrudan dever ölçümünün yapılması ve yalpa açısına göre dever ölçümünün yapılması olmak üzere iki adet analiz kriteri bulunmaktadır. Doğrudan dever ölçümünün yapılması kriteri için araca entegre çalışan eğim sensörü, dever açısını araca yanal düzlemde etki edecek büyük kuvvetlerin olmadığı durumlarda doğru bir şekilde ölçebilmektedir. Bu bağlamda deverin ölçümü için analiz kriteri şu adımlarla belirlenmiştir;

- Türkiye'de uygulanan standart dever değeri \%8'dir.

- \%8'lik eğim değeri 4,6 'ye karşılık gelmektedir.

- Eğim Sensöründe yapılan kalibrasyon ve hata payları çalışmasında eğim sensörünün ölçülen eğim derecesi üzerinde $\% 5$ 'lik bir hata oranı olduğu tespit edilmiştir. Bu bağlamda $\pm 4,6^{\circ}$ 'ye karş1lık gelen $\% 5$ 'lik hata oran $1 \pm 0,2^{\circ}$ 'dir.

Sonuç olarak sensörün göstermesi gereken standart dever değeri $\pm 4,6^{\circ}$ değil bu hesaplamalara göre $\pm 4,4^{\circ}$ olarak belirlenmiştir. Böylece eğim sensörünün her bulduğu açı değerine $(X s)$, derece başına bulunan hata payı ( $X_{\text {hata }}$ ) çarpılıp eklenmiştir:

$$
\begin{aligned}
& X_{\text {hata }}=X_{s} * 0,005^{\circ} \\
& X=X_{\text {düzeltilmiş }}=X_{S} * X_{\text {hata }}
\end{aligned}
$$


Doğrudan dever ölçümünün alınmasında araca yanal düzlemde etki eden büyük kuvvetlerin bulunmaması sebebiyle yalpa açısı araçta oluşmamaktadır. Bu şartlar altında yol üzerindeki aracın sensör değerleri; araç jiroskop $Z$ eksenine göre düz olduğunda $X<-4,4$ veya $X>4,4$ ise deverin fazla verildiği söylenebilmektedir. Yalpa açısına göre dever ölçümünün yapılması kriteri için ise araca entegre çalışan eğim sensörü, yalpa açısını $(\theta)$ araca yanal düzlemde etki eden kuvvetler olduğu durumlarda ölçmektedir. Bu değer yapılan araştırmalar sonucunda Standart otomobiller için $\pm 7^{\circ}$ olmalıdır (Parczewski ve Wnek, 2017). Dikkat edilmesi gereken durum ise yalpa açı değerinin dever değerinin tersi yönde olacağıdır. Bu bağlamda viraj üzerinde uygulanan dever değerinin standartlara uygun olup olmadığını söyleyebilmek için şu adımlar belirlenmiştir;

- Sağ virajda $X>7^{\circ}$ ise yalpa açısı dışa doğrudur ve güvenilir sürüş değerinden fazla vermiştir. Dever eksik verilmiştir.

- Sağ virajda $X<0^{\circ}$ ise yalpa açısı içe doğrudur. Dever fazla verilmiştir.

- Sol virajda $X<-7^{\circ}$ ise yalpa açısı dişa doğrudur ve güvenilir sürüş değerinden fazla vermiştir. Dever eksik verilmiştir.

- Sol virajda $X>0^{\circ}$ ise yalpa açısı içe doğrudur. Dever fazla verilmiştir.

Burada standart dever değeri gibi net ifade edilen bir değer yerine araştırmalar neticesinde ortaya çıkan bir değer bulunmaktadır. Bu sebeple yalpa açısına göre ölçüm yapılırken sensör kartının verdiği hata payı ölçüm esnasında ihmal edilmiştir.

\section{Sonuçlar}

Çalışmada kullanılan araç ile Şekil 9' da belirtilen güzergahlarda veri alımları yapılmıştır. İki ayrı güzergâh üzerinde başlangıç ve bitiş noktaları arasında saniyede 50 veri alınmıştır. Aracın üzerindeki GPS sensörü saniyede 1 adet konum verisi aldığ 1 için 2 GPS noktası arasında kalan eğim ve jiroskop verilerinin konum noktaları CBS sorgularında gösterilememektedir. $\mathrm{Bu}$ sebeple, 2 GPS noktası arasında kalan eğim ve jiroskop sensör verilerinin, araştırılan hatalı dever koordinatlarının üzerinde tekrarlı olup olmadığı veri setinde gözlemle incelenmiştir. Bu bağlamda aşağıda verilen alt bölümlerde CBS sorgu haritaları bu şekilde gösterilmiştir. Saniyede 10 ve 25 adet veri alımı yapılan diğer dizinler ise ortaya çıkan sonucu destekleyici birer sağlama verisi olarak alınmış olup sonuç kısmında verilmiştir.

Çalışmada kullanılan sensörler tabi ki tam doğrulukla ölçüm yapamamaktadır. Bu hatalar olabildiğince en aza indirilmeye çalışılmıştır. Sadece, 2,5 m'lik GPS hatası kabul edilebilir görülmüş, herhangi bir düzeltme yapılmamıştır. Kısa bir zamanda karayollarındaki hatalı deverlerin hangi mevkilerde olduğunu belirlemek ve karar vericilere bir ön rapor sunmak için bu hata ihmal edilebilirdir. Bu yüzden, konum verileri hatalarının çalışma bulgularına etkisi yok denecek kadar azdır.

\subsection{Hatalı Dever Noktalarının Doğrudan Tespit Edilmesi}

Yol üzerine uygulanan dever değerinin fazla verildiğini söyleyebilmek için deverle verilen eğimle dönen aracın tekerlek seyrini düz olarak koruduğu veri alanları analiz edilmiştir. Sorgulama sonucunda CBS haritaları üzerinde sol virajda olması gereken 4,4 ' lik eğim açısı sağ virajlarda gözüküyor, sağ virajda olması gereken $4,4^{\circ}$ 'lik eğim açısı sol virajlarda gözüküyor ise bu noktalarda eğim viraj yönünün tersi yönünde değer almış anlamına gelmektedir. Şekil 10 ve Şekil 11'de görüldüğü üzere genellikle konum noktaları bu durumla ilgili olarak hata vermiştir. 


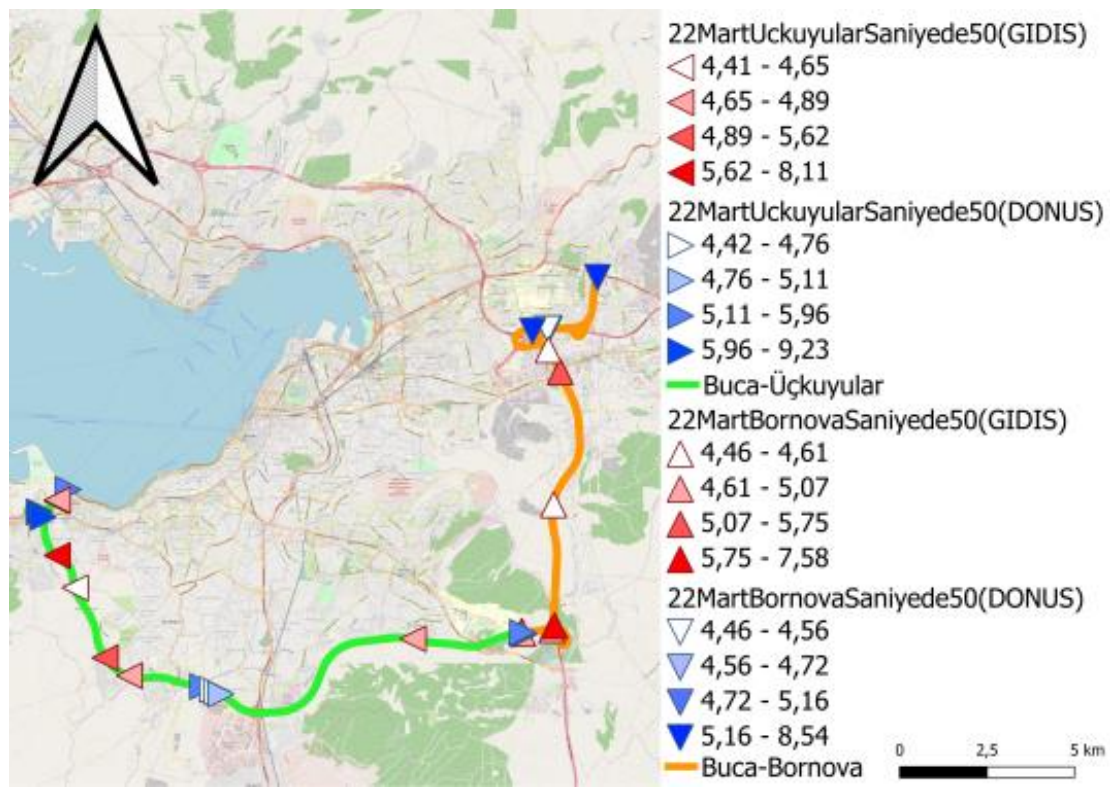

Şekil 10. Seyir Hali Düz Durumda Standart Dever Değerinden Yüksek Olan Yol Noktaları Buca-Üçkuyular ve Buca-Bornova Sorgusu

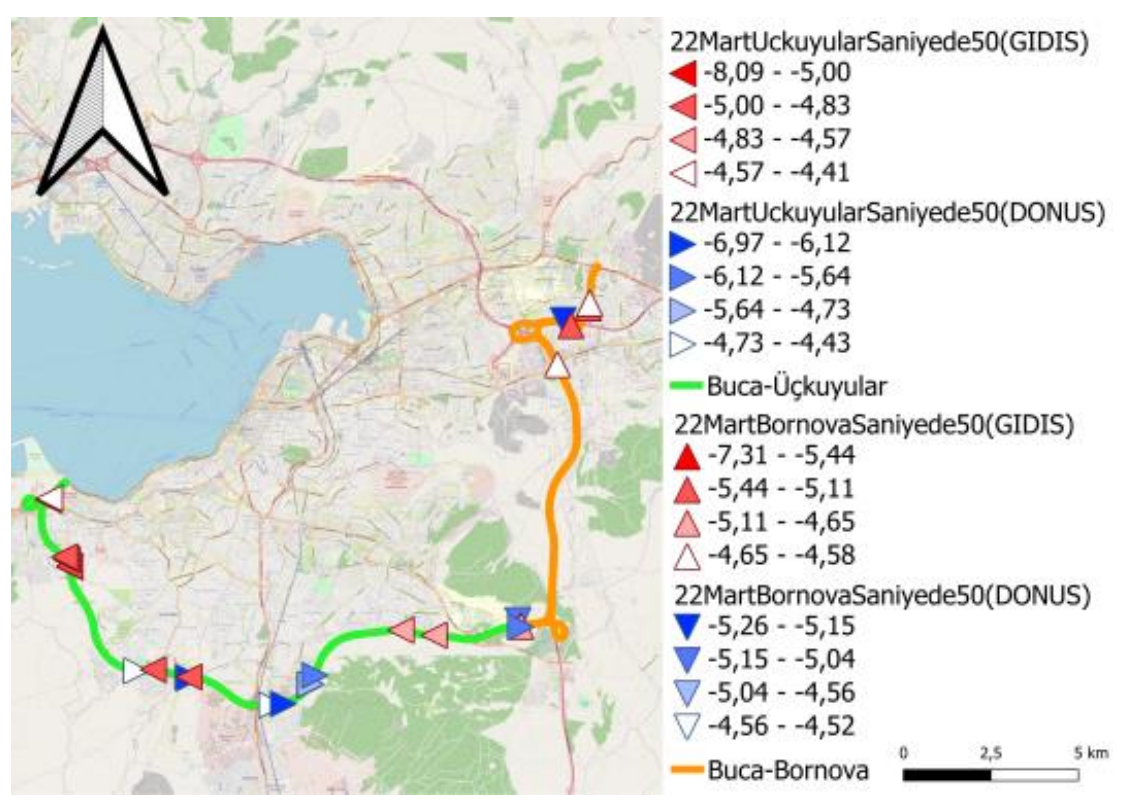

Şekil 11. Seyir Hali Düz Durumda Standart Dever Değerinden Yüksek Olan Yol Noktaları Buca-Üçkuyular ve Buca-Bornova Sorgusu

Otoyollardaki eğim ile dönüş sağlanan uzun virajlarda tekerlek seyri düz olduğu için bu verilerle birlikte viraj bulunmayan yolun düz kısımları CBS haritaları üzerinde ayırt edilmelidir. Deverin belirlenen standartlardan yüksek olarak uygulandığı yol noktalarının analizi sonucunda güzergahlara göre elde edilen verilerin özellikleri Tablo 7'de verilmiştir.

Tablo 7. Doğrudan sorgulanan hatalı dever noktaları sayısı (deverin fazla olduğu noktalar)

\begin{tabular}{lll}
\hline Veri Alımı (adet/sn) & Buca - Bornova & Buca - Üçkuyular \\
\hline 10 & 11 & 21 \\
25 & 14 & 62 \\
50 & 43 & 105 \\
Toplam & 68 & 188 \\
\hline
\end{tabular}




\subsection{Hatalı Dever Noktalarının Yalpa Açısına Göre Tespit Edilmesi}

Yol üzerinde uygulanan dever değerinin yalpa açısına göre fazla verildiğini söyleyebilmek için dever üzerindeki aracın tekerlek seyrini viraj yönünde koruduğu veri alanları incelenmelidir. Yalpa açısının viraj yönüyle aynı yönde olduğu durumlarda dever üzerindeki taşıt içe doğru kayma yapabilir. Yalpa açısına göre bakılan bu durum dever standardının aşıldığını değil yol üzerine uygulanması gereken dever değerinin fazla verildiği anlamına gelmektedir. $\mathrm{Bu}$ bağlamda yapılan sorgulardan dever değerinin fazla olduğu konumlar Şekil 12 ve Şekil 13'de verilmiştir. Sol virajda yalpa açısının içe doğru olduğu noktaları bulmak için dönüş yönü sol seyirde iken taşıtın yalpa açısı $0^{\circ}$ 'den büyük olmalıdır. Aynı şekilde, sağ virajda yalpa açısının içe doğru olduğu noktaları bulmak için dönüş yönü sağ seyirde iken taşıtın yalpa eğimi $0^{\circ}$ 'den küçük olmalıdır.

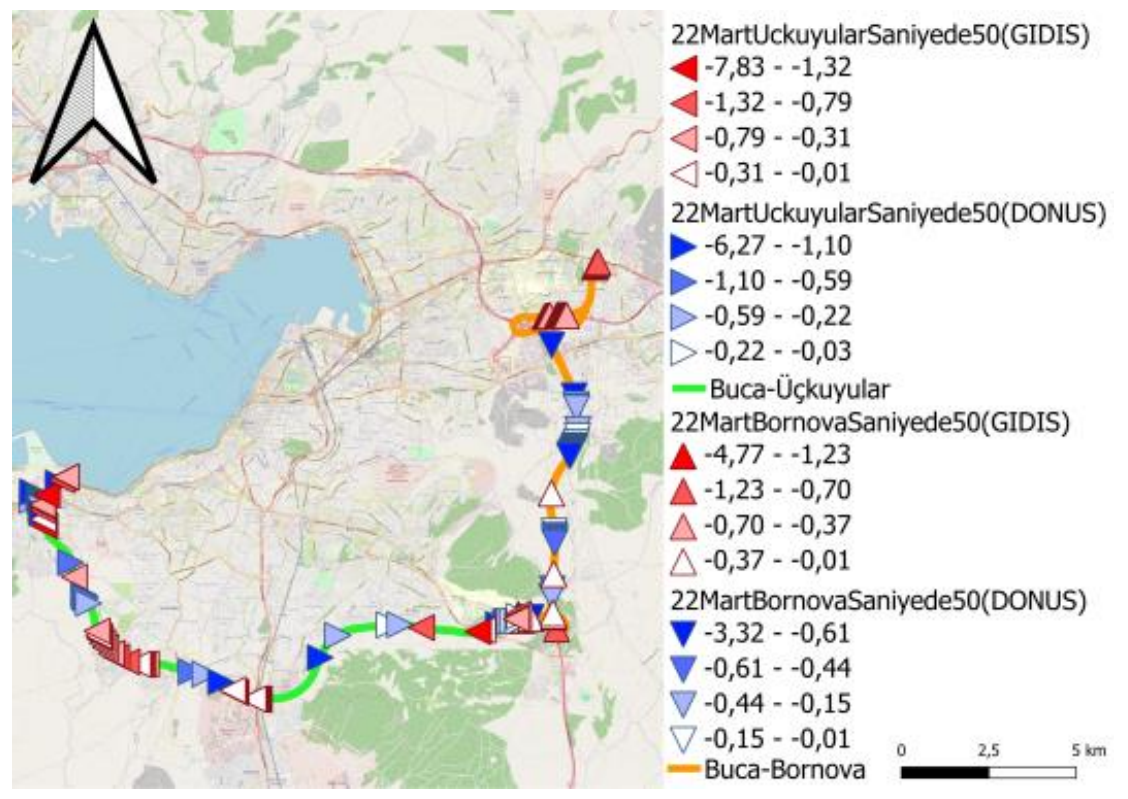

Şekil 12. Yalpa Açısına Göre Standart Dever Değerinden Yüksek Olan Yol Noktaları Buca-Ü̧̧kuyular ve BucaBornova Sorgusu

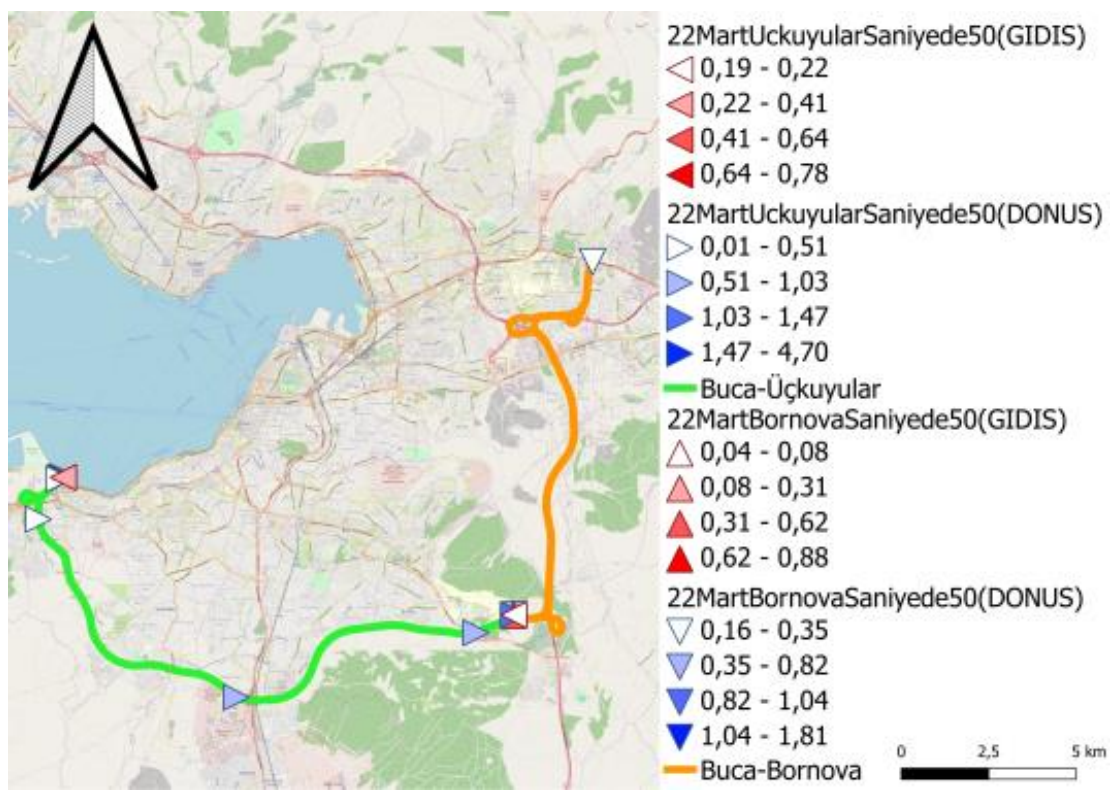

Şekil 13. Yalpa Açısına Göre Standart Dever Değerinden Yüksek Olan Yol Noktaları Buca-Üçkuyular ve BucaBornova Sorgusu 
Burada bulunan değerlerden yalpa açısının içe doğru olduğu konum verileri, doğrudan dever ölçümü yapılan konum verilerini desteklemesi beklenir. Eğer bu veriler yol üzerinde farklılık gösteriyor ise yolun kimi noktalarında birleşip kimi noktalarında ayrılma yaparak yol üzerindeki taşıta uzun vadede zikzak yaptırdığı anlamına gelmektedir. Yalpa açısına göre deverin belirlenen standartlardan yüksek olarak uygulandığ 1 yol noktalarının analiz sonucu Tablo 8'de verilmiştir.

Tablo 8. Hatalı dever noktalarının yalpa açısına göre veri sayısı (deverin fazla olduğu noktalar)

\begin{tabular}{lll}
\hline Veri Alımı (adet/sn) & Buca - Bornova & Buca - Üçkuyular \\
\hline 10 & 65 & 52 \\
25 & 156 & 291 \\
50 & 318 & 383 \\
Toplam & 539 & 726 \\
\hline
\end{tabular}

Yol üzerinde uygulanan dever değerinin yalpa açısına göre eksik verildiğini söyleyebilmek için dever üzerindeki aracın tekerlek seyrini viraj yönünde koruduğu veri alanları incelenmelidir. Yalpa açısının viraj yönüyle ters yönde olduğu durumlarda otomobiller için öngörülen $7^{\circ}$ 'lik yalpa değeri aşılırsa o bölgede deverin eksik verildiği çalışma kapsamında söylenebilir. Bu bağlamda yapılan sorgulardan deverin eksik olduğu konumlar Şekil 14 ve Şekil 15'de verilmiştir. Sağ virajda yalpa açısı sola doğru en fazla $7^{\circ}$, sol virajda yalpa açısı sağ doğru en fazla $-7^{\circ}$ olmalıdır.

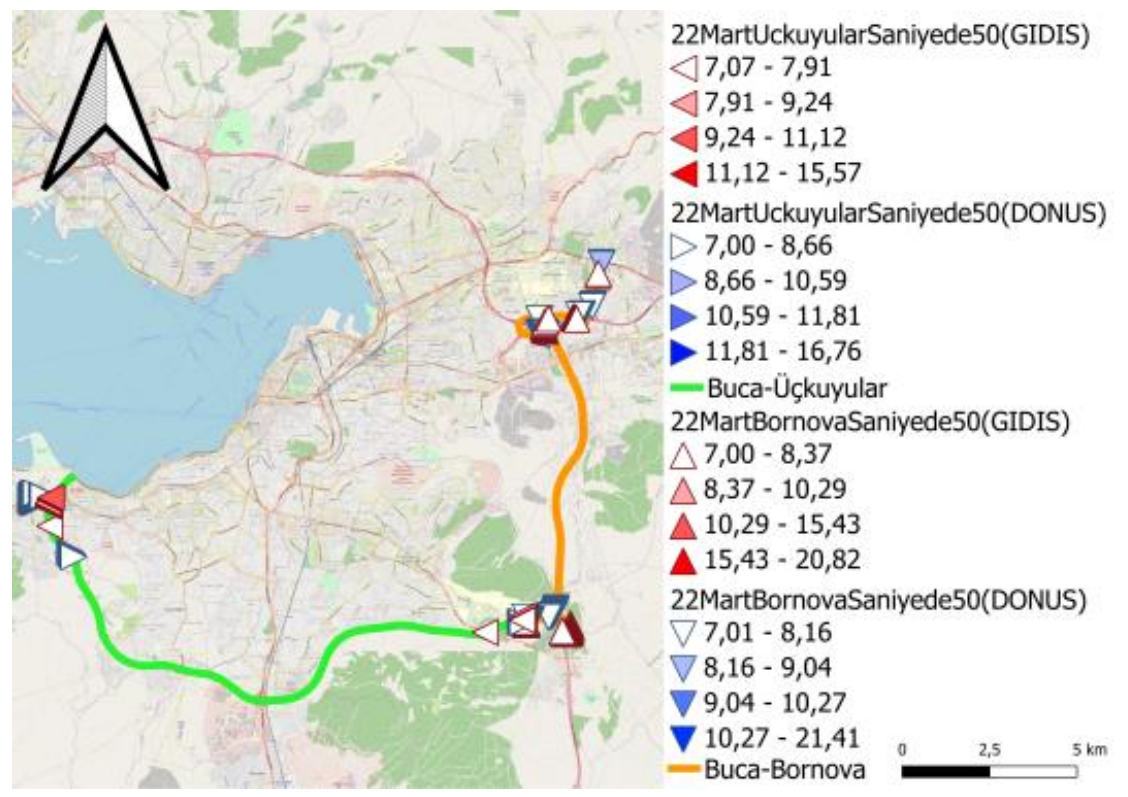

Şekil 14. Yalpa Açısına Göre Dever Değerinin Yetersiz Kaldı̆̆ı Yol Noktaları Buca-ÜÇkuyular ve Buca-Bornova Sorgusu 


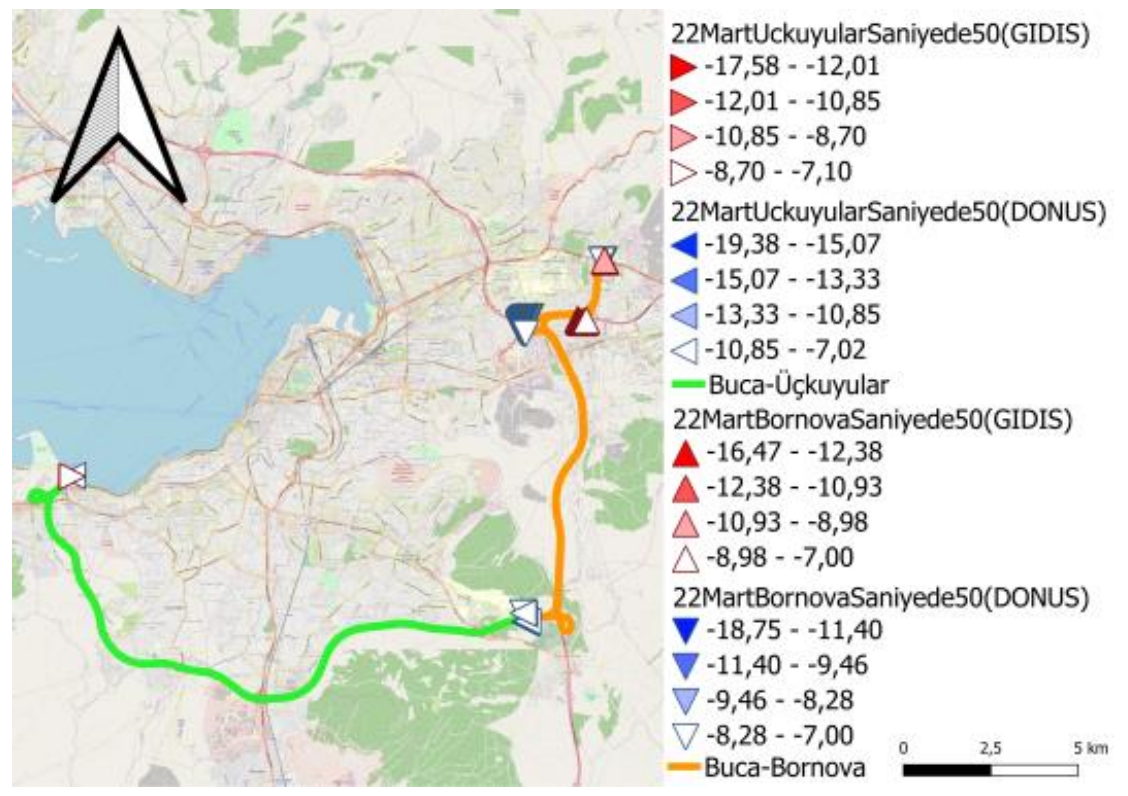

Şekil 15. Yalpa Açısına Göre Dever Değerinin Yetersiz Kaldı̆̆ı Yol Noktaları Buca-Üçkuyular ve Buca-Bornova Sorgusu

Tablo 9'da yalpa açısına göre deverin belirlenen standartlardan eksik olarak uygulandığı yol noktalarının analizi sonucunda, güzergahlara göre elde edilen verilerin özellikleri verilmiştir.

Tablo 9. Hatalı dever noktalarının yalpa açısına göre veri sayısı (deverin eksik olduğu noktalar)

\begin{tabular}{lll}
\hline Veri Alımı (adet/sn) & Buca - Bornova & Buca - Üçkuyular \\
\hline 10 & 1.117 & 541 \\
25 & 2.932 & 1.041 \\
50 & 3.572 & 1.450 \\
Toplam & 7.621 & 3.039 \\
\hline
\end{tabular}

Uygulamaya göre hatalı dever noktalarının doğrudan tespit edilmesi aşağıdaki sorgulara göre olmakta ve bu sorgulara göre de hangi sonuçların elde edildiği belirtilmektedir. Bu sorgular yatay eğimde elde edilen verilerin araç hareketine bağlı olarak incelenmesine olanak sağlamıştır. Bilinmelidir ki virajlarda araç üzerindeki sensör yolun dever değerini değil deverin araca uyguladığı eğim değerini ölçmektedir. Bu bağlamda seyir halinin düz olup dönüşün sadece deverle sağlandığı yol noktaları ile sağ veya sol virajda deverin araca uyguladığı eğim noktalarındaki ölçüm kriterleri birbirlerine karıştırılmadan analiz edilmiştir.

- "X Egim" > 4.4 AND "Donus Yonu" = 'duz' ise sonuç = (Dever Fazla)

- "X Egim" < -4.4 AND "Donus Yonu" = 'duz' ise sonuç = (Dever Fazla)

Uygulamaya göre hatalı dever noktalarının yalpa açısına göre tespit edilmesi aşağıdaki sorgulara göre olmaktadır.

- $\quad$ "X Egim" > 0 AND "Donus Yonu" = 'sol' ise sonuç = (Dever Fazla $)$

- "X Egim" < 0 AND "Donus Yonu" = 'sag' ise sonuç = (Dever Fazla)

- "X Egim" > 7 AND "Donus Yonu" = 'sag' ise sonuç = (Dever Eksik)

- "X Egim" <-7 AND "Donus Yonu" = 'sol' ise sonuç = (Dever Eksik)

Çalışma kapsamında Buca-Bornova ve Buca-Üçkuyular güzergahlarından alınan toplam dever verileri, dever verileri üzerinde yapılan sorgu sonuçları, toplam dever verilerinin sorgu sonucunda ortaya çıkan toplam hatalı dever verilerine oranı Tablo 10'da gösterilmiştir. 
Tablo 10. Toplam dever verileri ile sorgu sonucundaki toplam hatalı dever verileri

\begin{tabular}{lll}
\hline Açıklama & Buca - Bornova & Buca - Üçkuyular \\
\hline Elde Edilen Toplam Veri Sayısı & 64.487 & 83.413 \\
Her İki Güzergahtaki Toplam Veri Sayısı & 147.900 & \\
Güzergahlara Göre Toplam Dever Hata Sayısı & 8.228 & 3.946 \\
Güzergahlara Göre Dever Hata Oranı & $\% 13,39$ & $\% 5,35$ \\
Her İki Güzergahtaki Toplam Dever Hata Sayısı & 13.100 & \\
Her İki Güzergahtaki Toplam Dever Hata Oranı & $\% 8,85$ & \\
\hline
\end{tabular}

\section{Tartışma}

Bu çalışma otomotiv mühendisliği, ulaştırma mühendisliği, bilgisayar programlama, bilgisayar donanımı ve CBS'yi bir araya getirip kent dışı otoyollardaki hatalı dever noktalarını tespit etmek için sistemsel bir yaklaşım sunmaktadır. Bu bağlamda belirlenen yol güzergahlarında, araç üzerinde çalışan gömülü sistem yardımıyla dever ölçümleri yapılmış olup elde edilen veriler CBS haritalarında belirlenen ölçüm kriterlerine göre gösterilmiştir. Verilerden elde edilen dever hata raporu KGM'ye veya ilgili KGM operasyonel birimine karar vermesinde fayda sağlayacak bir sistemi oluşturmaktadır.

Çalışmada, karar verici merciinin tek bir noktaya odaklanarak karar vermesinden ziyade, gömülü sistem uygulamasıyla farklı bir bakış geliştirilerek karar vericiye alternatif çözümler üretilmesi amaçlanmıştır. Bu bağlamda ortaya çıkan sonuçlar karar verici merciiye raporlanarak ileriye dönük şu faktörlerde fayda sağlamaktadır;

Maliyet: Çalışmada kullanılan donanım gereçlerinin maliyeti oldukça ucuzdur. Herhangi bir bozulma durumunda yeni araç ve gereçler kolayca tedarik edilebilmektedir. Esas olarak, maliyeti araç yakıtı oluşturmakta, maliyet ölçüm yapılacak karayolunun uzunluğu ile doğru orantilidir.

Zaman: Uygulama hareket halindeki araç üzerinde çalıştı̆̆ 1 için istenilen otoyol bölgesinde veya bir noktadan diğer noktaya kadar olan otoyol aralığında hızlı bir şekilde veri alımı yaparak sonuç elde edebilmektedir. $\mathrm{Bu}$ sayede yol bakım onarım çalışmalarında bir ön rapor oluşturularak sorunlu yol noktaları daha hızlı belirlenebilecektir. Ayrıca, gömülü sistem yardımı ile elde edilmiş veriler CBS yazılımında içe aktarılarak hatalı dever noktaları harita üzerinde gösterilebilmekte, coğrafi sorgu ve analizler ile bilgi çok kısa bir sürede üretilebilmektedir.

İş Gücü: Çalışılacak yol üzerinde uygulamanın tarama yapması ve düzeltilmesi gereken yol noktalarını belirlemesi ciddi anlamda iş yükünü kurum içinde azaltacaktır.

İnsan Hayatı: Genellikle yol üzerindeki hatalı dever noktaları kaza veya şikâyet üzerine incelenmektedir. Çalışma ile yol üzerindeki dever hatalarının belirlenmesi yol üzerindeki kusurlu noktaların trafik kazaları yaşanmadan önce tespit edilmesini sağlayacaktır.

Kullanılan yöntem ileride geliştirilebilir niteliktedir. Bu yönüyle çalışma kapsamında kent dışı otoyollardaki hatalı dever tespitine dair taşıt üzerinde çalışan gömülü sistem uygulamaları günümüzde KGM gibi kurumlarda veya özel sektörde kullanılması önerilmektedir. Trafik kazaları yaşanmadan veya yaşanmasına sebebiyet verecek faktörler ortaya çıkmadan karayolları üzerinde yapılan bu çalışma, KGM içerisindeki yol ve onarım bakım faaliyetlerinde dinamizmi arttıracağı da öngörülmüştür.

Bu çalışma sonucunda karayollarında bulunan hatalı dever noktaları yerinde ölçümlerle elde edilen dever açıları ile karşılaştırılamamıştır. Çalışma sonucunda elde edilen hatalı dever noktalarının, yolun yapım aşamasında yapılan ölçümlerle karşılaştırması hatalı ölçüm değerini veya zaman faktörüne bağlı olarak değişen dever değerlerinin boyutunu ortaya çıkarabilecektir. 
$\mathrm{Bu}$ sebeple, gelecekteki bu veya buna benzer çalışmalarda elde edilen verilerin yerinde ölçümlerle elde edilen verilerle karşılaştırılması oldukça önem arz etmektedir. Ayrıca, çalışma güzergahları üzerindeki oluş biçimleriyle birlikte trafik kazalarının konumları hatalı dever bulgusuna ait konumlarla karşılaştırılması elde edilen bulguların niteliğini arttıracağı öngörülmüştür. Bu yüzden, ilerdeki çalışmalarda kullanılan yöntem ile yerinde ölçümlerin karşılaştırılması ve elde edilen bulgular üzerinde yol geometrisine bağlı trafik kazalarının yaşanıp yaşanmadığı incelenecektir.

Çalışma sonucunda elde edilen bulgular belirli teknik özelliklere sahip bir araç kullanılarak elde edilmiştir. Farklı bir model araç kullanımında bazı bulguların farklı olması olasıdır. Bunun yanında, gelecekte uygulamanın daha sağlıklı sonuçlar verebilmesi için çalışma kapsamında çalışan sensörlerin araç gövdesi yerine süspansiyon sistemine ve aks bölgesine yakın alt takımlara konumlandırılabilir. Bu sayede aracın yol ile tepkimeye girdiği ilk noktadan veri alımı sağlanarak daha net ölçümler yapılabilir.

GPS'den elde edilen koordinatların saniyede 1 adet, sensörlerden ise saniyede 50 adet veri alınması iki koordinat arasında kalan ve koordinatlandırılamayan noktalarda sorun teşkil etmektedir. İleriki çalışmalarda interpolasyon yöntemi ile arada kalan noktaların koordinatlandırılması olasıdır. Ayrıca, elde edilen veriler üzerindeki enlem ve boylam bilgileri üzerinde birden fazla eğim ve jiroskop verisi bulunmaktadır. Her bir veri parçacığına bir konumlama yapılması sensör veri alım hızlarının konum veri hızına eşit olmasıyla çözülebileceği düşünülmektedir.

Zamanla piyasaya sürülecek olan daha gelişmiş ivme ve jiroskop sensörleri araç üzerinde kullanılabileceği öngörülmektedir. Süspansiyon sistemindeki hareketlenmeleri inceleyen ek bir sensör kullanımı verilerin doğrulama aşamasında daha yararlı olabileceği öngörülmektedir.

\section{Etik Kurul Onay Beyanı}

İlgili çalışmada insan veya hayvan katılımcılardan veri toplanmadığı için etik kurul izni gerekmemektedir. 


\section{Kaynakça}

Akpınar, M. V. (2017). Örneklerle Karayolu Tasarımı. İstanbul: Birsen Yayınevi.

Charbeneau, R. J., Jeong, J. E. ve Barrett, M. E. (2008). Highway Drainage at Superelevation Transitions. Texas, ABD: University of Texas at Austin Center for Transportation Research.

Design Quality Assurance Bureau (2003). Recommendations for AASHTO Superelevation Design. New York: Design Design Quality Assurance Bureau NYSDOT.

Gupta, A., Hu, S., Zhong, W., Sadek, A., Su, L. ve Qiao, C. (2020). Road grade estimation using crowd-sourced smartphone data. 19th ACM/IEEE International Conference on Information Processing in Sensor Networks (IPSN), 21-24 Nisan, 313-324. doi: 10.1109/IPSN48710.2020.00-2

KGM (2016). Karayolu Tasarım El Kitabl. Ankara: Karayolu Genel Müdürlügüü.

KGM (2021). Trafik Kazaları Özeti 2020. Ankara: Karayolları Genel Müdürlüğü.

Lamm, R. (1984). Driving Dynamic Considerations: A comparison of German and American friction coefficients for highway design. 63rd Annual Meeting of the Transportation Research Board, 13-20 Ocak, 16-20.

Lim, C-S. ve Choi, Y-W. (2011). Analysis on the driving safety and investment effect using severity model of fatal traffic accidents. Journal of Korean Society of Transportation. 29(3), 103-114.

Nilsson, A. ve Lingefelt, H. (2011). Estimation of Vehicle Roll Angle (yayımlanmamış yüksek lisans tezi). Lund University, İsveç.

Parczewski, K. ve Wnek, H. (2017). The influence of vehicle body roll angle on the motion stability and maneuverability of the vehicle. Combustion Engines. 168(1), 133-139. doi: 10.19206/CE-2017-121

Pasias, P., Apostoleris, K., Matragos, V., Mertzanis, F. ve Mavromatis, S. (2020) Passenger cars safety assessment on interchange ramps. Proceedings of the 6th International Symposium on Highway Geometric Design. Amsterdam, 23-28 Haziran.

Patil, S. B., Attar, S., Dugani, D., Desai T. ve Mahabri S. (2019). Study of geometric features of road and accident rate. International Research Journal of Engineering and Technology. 6(4), 430-432.

Soytürk, M., Doğan, F., Şaşmaz, E. ve Böyük, Ş. (2014). Yol yüzey bozuklarının tespit ve analizi. 22nd Signal Processing and Communications Applications Conference (SIU), Trabzon, 23-25 Nisan, 1897-1901. doi: 10.1109/SIU.2014.6830625.

Sulistyono, S., Kriswardhana, W. ve Hayati, N. N. (2020) Victim fatality study of traffic accident at KM SBY 106+200 (Jalan Pantura Probolinggo-Situbondo) in efforts to reduce the traffic accident risk. Journal of Indonesia Road Safety. 3(2), 112-120.

Süzen, A. A., Deniz, Ö. ve Çetin, A. (2017). Kafa hareketleri ile kontrol edilebilen tekerlekli sandalye, Mehmet Akif Ersoy Üniversitesi Fen Bilimleri Enstitüsü Dergisi. Özel Sayı 1 (2017), 66-72. 
Tsai, Y. (James) ve Ai, C. (2017). Automated superelevation measurement method using a lowcost mobile device: an efficient, cost-effective approach toward intelligent horizontal curve safety assessment. Transportation Research Record, 2621(1), 62-70. doi: $10.3141 / 2621-08$

Tuncel, U. ve Baybura, T. (2011). Gerçek zamanlı kinematik GPS ve ivmeölçer yardımı ile bazı yol geometrik standartlarının trafik kazalarına etkisinin araştırılması. Harita Teknolojileri Elektronik Dergisi, 3(3), 16-25.

Uyurca, Ö. ve Atılgan, İ. (2018). Ankara ilinde meydana gelen trafik kazalarının incelenmesi. Kent Akademisi. 11(33), 623-624.

Ünal, A. ve Çodur, M. Y. (2017). Trafik kazalarının meydana gelmesinde mühendislik hataları: Bursa ili örneği. International Conference on Advanced Engineering Technologies. Bayburt, 21-23 Eylül.

Vargas-Meléndez, L., Beatriz, B. L., Boada, M. J. L., Gauchia, A. ve Diaz, V. (2016). A sensor fusion method based on an integrated neural network and kalman filter for vehicle roll angle estimation. Sensors. 16(9). doi: 10.3390/s16091400

Yayla, N. (2004). Karayolu Mühendisliği. İstanbul: Birsen Yayınevi. 